\title{
Angka Kejadian Tuberkulosis Paru pada Anak dengan Imunisasi BCG di RSUD Al-Ihsan Bandung Bulan Januari-Juni 2019
}

\author{
Fitri Janur Rakhmawati, ${ }^{1}$ Arief Budi Yulianti, ${ }^{2}$ Widayanti ${ }^{3}$ \\ ${ }^{1}$ Program Studi Pendidikan Dokter, ${ }^{2}$ Bagian Biologi Medik dan Histologi, ${ }^{3}$ Departemen Fisiologi \\ Fakultas Kedokteran Universitas Islam Bandung
}

\begin{abstract}
Abstrak
Tuberkulosis (TB) yang dikenal sebagai salah satu penyebab 10 kematian tertinggi di dunia merupakan penyakit infeksi menular disebabkan oleh bakteri Mycobacterium tuberculosis. Tuberkulosis paru dapat diderita oleh anak termasuk pada usia $0-5$ tahun. Berbagai faktor risiko penularan TB pada anak, yaitu usia jenis kelamin, status gizi, dan status imunisasi BCG. Penelitian ini berupa deskriptif bertujuan menganalisis angka kejadian TB anak dengan karakteristik riwayat imunisasi BCG pada pasien TB anak yang baru didiagnosis di RSUD Al-Ihsan Bandung pada bulan Januari-Juni 2019. Desain ini menggunakan metode deskriptif yang diperoleh dari rekam medis pasien TB. Hasil penelitian didapatkan bahwa penderita TB paru anak yang datang ke Poli Anak RSUD Al-Ihsan Bandung pada bulan Januari-Juni 2019 sebanyak 211 penderita TB dengan jumlah kejadian terbanyak pada bulan Mei. Jumlah pasien TB anak usia $1-24$ bulan 30 orang $(25,6 \%)$ dan usia $25-60$ bulan 87 orang $(74,4 \%)$, jenis kelamin laki-laki 59 orang $(50,4 \%)$ dan perempuan 58 orang $(49,6 \%)$. Pasien yang memiliki tanda parut 98 orang $(83,8 \%)$ dan tidak memiliki tanda parut 19 orang (16,2\%). Simpulan, penderita TB paru anak banyak terjadi pada usia 1-24 bulan, jenis kelamin laki-laki, dan memiliki riwayat imunisasi BCG.
\end{abstract}

Kata kunci: BCG, tuberkulosis anak, status gizi

\section{Numbers of Lung Tuberculosis in Children with BCG Immunization in Al Ihsan Bandung Hospital Months January-June 2019}

\begin{abstract}
Tuberculosis (TB), known as one of the 10 highest causes of death in the world, is an infectious disease caused by the bacterium Mycobacterium tuberculosis. Pulmonary tuberculosis can be suffered by children including those aged O-5 years. Various risk factors for TB transmission in children are age, sex, nutritional status and immunization status of BCG. This descriptive research aims to analyze the incidence of pediatric TB with a characteristic history of BCG immunization in newly diagnosed pediatric TB patients at Al-Ihsan Regional Hospital Bandung in JanuaryJune 2019. This design used a descriptive method obtained from the medical records of TB patients. The results showed that patients with pulmonary TB who came to the Children's Polyclinic of Al-Ihsan Regional Hospital Bandung in January-June 2019 were 211 TB patients with the highest number of events in May. The number of TB patients in children aged 1-24 months were 30 children (25.6\%) and aged 25-60 months was 87 children (74.4\%), boys were 59 children $(50.4 \%)$ and girls were 58 people (49.6\%). Patients who had scar marks were 98 children (83.8\%) and did not have scar marks 19 children (16.2\%). In conclusion many children with pulmonary TB occur at 1-24 months of age, male, and have a history of BCG immunization.
\end{abstract}

Keywords: BCG, nutritional status, pediatric tuberculosis

Received: 6 February 2020; Revised: 17 July 2020; Accepted: 30 July 2020; Published: 31 July 2020

Koresponden: Fitri Janur Rakhmawati. Fakultas Kedokteran Universitas Islam Bandung. Jalan Hariang Banga No.2, Kota Bandung, Provinsi Jawa Barat. Telepon : 022-42-3368. 081809259027. Email : janurf@gmail.com. 


\section{Pendahuluan}

Penyakit tuberkulosis (TB) menduduki peringkat ke10 dengan kasus kematian tertinggi di dunia. Sebagian besar kasus TB berada di benua Asia salah satunya Indonesia yang menduduki peringkat ketiga dalam kasus TB. ${ }^{1}$ Tuberkulosis dapat berdampak pada anak memiliki prevalensi yang terus meningkat. Faktor yang dapat menyebabkan penularan pada anak ialah lama pajanan, daya tahan tubuh, dan lamanya penularan. ${ }^{2}$

World Health Organization (WHO) menyatakan secara global tuberkulosis menyebabkan kematian sekitar 1,3 juta penderita. Sebagian besar kasus TB berada di benua Asia (58\%) dan Afrika (27\%) dengan delapan negara yang memiliki insidensi TB tertinggi di dunia, yaitu India (27\%), Cina (9\%), Indonesia (8\%), Filipina (6\%), Pakistan (6\%), Nigeria (4\%), Bangladesh (4\%), dan Afrika Selatan (3\%). ${ }^{3}$

Penderita TB di indonesia meningkat sebanyak 28\% antara tahun 2017 dan 2018. ${ }^{3}$ Jumlah penderita TB tertinggi terdapat di tiga provinsi yang memiliki jumlah penduduk yang besar, yaitu Jawa Barat, Jawa Tengah, dan Jawa Timur. ${ }^{4}$ Rumah sakit Al-Ihsan ialah salah satu rumah sakit regional di Provinsi Jawa Barat yang memiliki kasus TB terbanyak pada bulan Oktober $2018 .^{5}$

Tuberkulosis adalah penyakit infeksi menular yang disebabkan oleh bakteri Mycobacterium tuberculosis yang memiliki karakteristik non-spora-forming, non motile, pleomorphic, batang melengkung, aerob, gram positif dengan panjang $1-5 \mu \mathrm{m}$ dan juga dikenal sebagai bakteri tahan asam (BTA), ${ }^{6,7}$ Penyebaran $M$. tuberculosis melalui cairan lendir atau biasa disebut mucus droplet nuclei yang ditransmisikan melalui udara dengan cara bersin, batuk, dan berbicara. ${ }^{7}$

Tuberkulosis paru anak di Indonesia mengalami peningkatan pada tahun 2015 sebanyak 8,49\% dibanding dengan tahun 2014 sebanyak 7,10\% meskipun jumlahnya relatif rendah dibanding dengan TB pada dewasa. Penderita TB secara umum banyak diderita oleh laki-laki (1.082,7) per 100.ooo) daripada perempuan (460.6 per 100.000). ${ }^{8}$ Hal ini terjadi karena faktor risiko yang buruk seperti merokok dan tidak patuh minum obat yang mempermudah reaksi infeksi dalam tubuh. Berbeda dengan penderita TB dewasa, jenis kelamin tidak terlihat berbeda pada anak karena penderita TB anak lebih banyak ditularkan oleh orang terdekat yang berkontak secara langsung. ${ }^{9,10}$

Prevalensi TB pada anak usia $<1$ tahun sekitar 0,2\%, usia 1-4 tahun $0,4 \%$, dan 5-18 tahun sekitar $0,3 \%{ }^{2}$ Sumber infeksi pada anak sebagian besar adalah orang dewasa yang menularkan di lingkungan terdekat. Paparan ini mengarah pada perkembangan lesi parenkim primer (fokus ghon) di paru dan dapat menyebar melalui kelenjar getah bening. Respons imun berkembang sekitar 4-6 minggu setelah infeksi primer. Dalam beberapa kasus, respons imun yang tidak cukup kuat menahan infeksi dan penyakit terjadi dalam beberapa bulan. Risiko berkembang menjadi penyakit meningkat ketika infeksi primer terjadi pada remaja usia kurang dari 10 tahun, anak sangat muda ( $0-4$ tahun), dan pada anak yang mengalami gangguan sistem imun. ${ }^{11}$ Pemberian imunisasi secara aktif dapat meningkatkan sistem imun agar dapat terhindar dari penyakit menular dalam jangka waktu yang panjang. ${ }^{12}$ Upaya pemerintah untuk mencegah penyakit TB dengan pemberian vaksin Bacille Calmette-Guerin (BCG) yang memiliki efektivitas bervariasi antara $0-80 \% .{ }^{13}$ Peningkatan strain baru di negara berkembang membuat efektivitas vaksin BCG menurun sehingga belum mampu mengendalikan perkembangan penyakit TB, tetapi hanya 70\% efektif mencegah bentuk TB yang berat seperti TB milier, TB paru berat, dan TB meningitis pada anak. ${ }^{14}$

Penelitian ini dilakukan untuk menganalisis angka kejadian TB paru pada anak usia $0-5$ tahun dengan riwayat imunisasi BCG yang diketahui melalui parut BCG.

\section{Metode}

Penelitian ini menggunakan metode berupa crosssectional yang bersifat deskriptif retrospektif dengan teknik total sampling. Populasi terjangkau penelitian ini adalah seluruh pasien anak yang baru didiagnosis TB paru di RSUD Al-Ihsan Bandung bulan JanuariJuni 2019.

Data penelitian ini diambil dari data sekunder berupa rekam medis meliputi usia, jenis kelamin, dan tanda parut BCG untuk menilai riwayat imunisasi BCG pada penderita tuberkulosis paru anak.

Sampel penelitian ini terdapat 117 orang yang memenuhi kriteria inklusi dan tidak termasuk kriteria eksklusi. Kriteria inklusinya, yaitu pasien anak yang didiagnosis $\mathrm{TB}$ paru dengan skoring $\geq 6$ poin dan berusia $0-5$ tahun. Kriteria eksklusinya, yaitu anak menderita HIV, keganasan, multi drug resistant tuberculosis, TB ekstraparu, dan infeksi atau penyakit kronis lain. Penelitian ini telah disetujui oleh Komite Etik Penelitian Kesehatan Fakultas Kedokteran Universitas Islam Bandung Nomor: 191/Komite Etik. FK/IV/2019.

\section{Hasil}

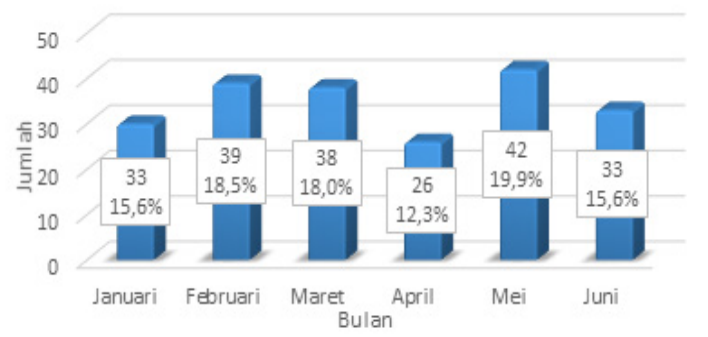

Gambar Persentasi Penderita Tuberkulosis Paru Anak pada Bulan Januari-Juni 2019 di RSUD Al-Ihsan Bandung

Penderita tuberkulosis paru anak yang mulai berobat di RSUD Al-Ihsan terbanyak pada bulan Mei berjumlah 42 orang $(19,9 \%)$.

Sebagian besar penderita tuberkulosis paru pada anak di RSUD Al-Ihsan berusia 1-24 bulan berjumlah 87 orang $(74,4 \%)$ dan sisanya usia $25-60$ bulan $(25,6 \%)$. 
Tabel Karakteristik Penderita Tuberkulosis Paru Anak berdasar atas Usia

\begin{tabular}{lcc}
\hline \multicolumn{1}{c}{ Variabel } & $\mathbf{n = 1 1 7}$ & Persentase (\%) \\
\hline Usia (bulan) & & \\
1-24 & 87 & 74,4 \\
$25-60$ & 30 & 25,6 \\
Jenis kelamin & & \\
Perempuan & 58 & 49,6 \\
Laki & 59 & 50,4 \\
Tanda parut & & \\
imunisasi ACG & & 83,8 \\
Ada & 98 & 16,2 \\
Tidak ada & 19 & \\
\hline
\end{tabular}

Jenis kelamin penderita tuberkulosis paru anak hampir sama antara laki-laki (50,4\%) dan perempuan (49,6\%). Sebagian besar penderita itu memiliki karakteristik tanda parut imunisasi BCG yang terlihat jelas $(83,8 \%)$.

\section{Pembahasan}

Penderita TB paru anak sebagian besar berusia 1-24 bulan (74,4\%). Masalah penyakit TB paru sudah mengenai usia anak dan balita yang didiagnosis pada kelompok usia < 1 tahun sebesar $2 \%$ dan kelompok usia 1-4 tahun sebesar $4 \% .^{15}$

Menurut WHO risiko terkena infeksi tuberkulosis jauh lebih besar pada bayi dan anak usia di bawah 5 tahun yang diperoleh dari orang dewasa yang menderita penyakit TB dan menularkannya melalui kontak secara langsung. ${ }^{9}$ Penderita TB anak disebabkan oleh penularan orang dewasa yang menderita penyakit TB melalui kontak secara langsung ke udara dalam bentuk percikan dahak.

Penularan TB sesama anak kemungkinan sangat kecil karena TB anak menginfeksi parenkim paru yang tidak menyebabkan refleks batuk sehingga jarang ditemukan gejala khas TB seperti batuk berdahak. ${ }^{16}$ Hal ini dapat terjadi bahwa imunitas seorang anak masih belum sempurna. Risiko penyebab utama selain imunitas antara lain kemiskinan, tidak memadai pelayanan $\mathrm{TB}$, penatalaksanaan kasus $\mathrm{TB}$ yang tidak memadai, efektivitas BCG, perubahan demografi karena peningkatan penduduk, dan pandemik HIV. ${ }^{18}$

Berdasar atas hasil penelitian penderita TB paru anak yang laki-laki hampir sama dengan perempuan. Penelitian Putra dkk. ${ }^{18}$ tahun 2018 ditemukan 60\% penderita laki-laki dan $40 \%$ perempuan. Penderita TB anak tidak menunjukkan perbedaan yang signifikan antara laki-laki dan perempuan karena faktor yang dapat menyebabkan penularan pada anak, yaitu lama pajanan, daya tahan tubuh, dan tingkat penularan. ${ }^{8}$ Berbeda dengan penderita TB dewasa lebih banyak laki-laki karena faktor merokok dan minum alkohol sehingga dapat menurunkan sistem pertahan tubuh dan kepatuhan minum obat. ${ }^{6}$ Faktor lingkungan masyarakat memengaruhi peningkatan prevalensi TB paru paling banyak pada kelompok usia produktif dan usia angkatan kerja (20-49 tahun) sekitar 58,3\% meliputi daerah endemis, kemiskinan, lingkungan tidak sehat (higiene dan sanitasi tidak baik), serta tempat penampungan umum (panti asuhan, penjara, atau panti perawatan lain). Selain itu, prevalensi TB paru tiga kali lebih tinggi di pedesaan dibanding dengan perkotaan serta empat kali lebih tinggi pada pendidikan rendah dibanding dengan pendidikan tinggi.

Penderita TB paru anak hampir seluruhnya memiliki tanda parut positif $(83,8 \%)$. Sebagian anak yang melakukan vaksin BCG memiliki komplikasi berupa pembentukan keloid lokal. ${ }^{20}$ Penelitian Aida dan Elsa ${ }^{21}$ tahun 2012 dinyatakan efektivitas vaksin BCG di Indonesia masih rendah (o-80\%) bergantung pada variabel perancu seperti genetis dan letak geografis. Hasil penelitian ini serupa dengan penelitian Retnaningsih ${ }^{22}$ tahun 2010 bahwa status imunisasi tidak berhubungan dengan kejadian tuberkulosis paru. Hal ini mungkin terjadi karena paparan yang terus menerus dengan kontak secara langsung pada penderita TB. Berbeda dengan penelitian Fajriah dkk. ${ }^{23}$ tahun 2016 menyatakan hubungan antara parut negatif dan angka kejadian tuberkulosis yang tinggi. Tanda parut dinilai untuk mengetahui riwayat imunisasi BCG yang digunakan untuk mencegah kejadian TB paru.

\section{Simpulan}

Simpulan penelitian ini adalah jumlah penderita tuberkulosis pada anak rawat jalan dan baru terdiangnosis diperoleh 211 penderita TB paru anak. Penderita tuberkulosis paru anak banyak terjadi pada anak berusia 1-24 bulan, hampir sama antara laki-laki dan perempuan, serta sebagian besar memiliki riwayat imunisasi BCG.

\section{Ucapan Terima Kasih}

Ucapan terima kasih penulis sampaikan kepada RSUD Al-Ihsan Bandung bagian Rekam Medis, Pak Agus selaku bidang penelitian di RSUD Al-Ihsan Bandung, dan semua pihak yang terlibat dalam penelitian ini.

\section{Daftar Pustaka}

1. World Health Organization. Global tuberculosis report 2018. Geneva: WHO; 2018.

2. Apriliasari R, Hestiningsih R, Udiyono A. Faktor yang berhubungan dengan kejadian TB paru pada anak (studi di seluruh puskesmas di Kabupaten Magelang). J Kesehat Masy. 2018;6:298-307.

3. World Health Organization. Global tuberculosis report 2019. Geneva: WHO; 2019.

4. Pola S. Bisakah tuberkulosis di Indonesia dieliminasi. Dalam: Awahita R, Tim CV Jejak, penyunting. Indonesia bebas tuberkulosis. Sukabumi: CV Jejak, anggota IKAPI; 2019. hlm. 28.

5. RSUD Al-Ihsan Bandung [Internet]. Bandung: 10 besar penyakit | RSUD Al-Ihsan Provinsi Jawa Barat; 2018 [updated 4 Des 2018; diunduh 2 Januari 2020]. Tersedia dari: rsudalihsan. 
jabarprov.go.id > page > 902-10-Besar-Penyakit.

6. Marlina I, Nuning K. InfoDatin: Pusat Data dan Informasi Kementrian Kesehatan RI. Jakarta Selatan: Kementrian Kesehatan RI; 2018.

7. Robert M, Kliegman M, Nelson textbook of pediatrics. Edisi ke-20. St Geme J, penyunting. Canada: Saunders; 2015.

8. Ministry of Health Republic of Indonesia, World Health Organization. State of health inequality: Indonesia. Geneva: WHO; 2017.

9. World Health Organization. Guidance for national tuberculosis programmes on the management of tuberculosis in children. Geneva: WHO: 2006.

10. Kementrian Kesehatan RI. Petunjuk teknis manajemen dan tatalaksana TB anak. Jakarta: Kemenkes RI; 2016.

11. Beck M. Ilmu gizi dan diet. Yogyakarta: Yayasan Essentia Medica; 2000.

12. Riani RES, Machmud PPB. Kasus kontrol hubungan imunisasi bcg dengan kejadian TB paru pada anak tahun 2015-2016. Sari Pediatr [database on internet]. 2018;19(6):321-7. (diunduh 2 Februari 2019). Tersedia dari: https:// saripediatri.org/index.php/saripediatri/article/ download/121/115.

13. Brosch R, Gordon SV, Garnier T, Eiglmeier K, Frigui W, Valenti P, dkk. Genome plasticity of BCG and impact on vaccine efficacy. Proc Natl Acad Sci. 2007;104:5596-601.

14. Queensland Health. Lembar fakta vaksinasi BCG. Queensl Heal. 2017 Jan: 1-4.

15. Kemenkes RI. Laporan Riset Kesehatan Dasar (Riskesdas) tahun 2013. Jakarta: Kementrian Kesehatan RI; 2013.
16. Nur Lailatul, Rohman S, Azar Yoga W. Upaya keluarga untuk mencegah penularan dalam perawatan anggota keluarga dengan TB paru. J Keperawatan. 2015 Juli;6(2):108-16.

17. Canadian Thoracic Society and The Public Health Agency of Canada and Licensor. Chapter 2, Transmission and pathogenesis of tuberculosis. Canada Tuberculosis Standards. Edisi ke-7. 2014.1-16. (diunduh 5 Januari 2019) Tersedia dari: http://www.lung.ca/cts-sct/pdf/ tbstando7 e.pdf.

18. Manalu HSP. Faktor-faktor yang mempengaruhi kejadian TB paru dan upaya penanggulangannya. J Ekol Kesehat. 2010;9(4):1340-6.

19. Putra AS, Fitriani PG, Eliska, Muchti YP. Analisis faktor yang berhubungan dengan kejadian tuberkulosis paru anak di RSUD Sibuhan. J Berkala Epidemiol. 2018 Dec 31;6(3):268-75.

20. Apriliasari R, Hestiningsih R, Udiyono A. Faktor yang berhubungan dengan kejadian TB paru pada anak (studi di seluruh puskesmas di Kabupaten Magelang). J Kesehat Masy. 2018;6:298-307.

21. Aida F, Elsa Y. Peranan imunisasi BCG terhadap pencegahan penyakit tuberkulosis. Makalah imunologi. Padang: 2012. hlm. 1-7.

22. Retnaningsih E. Model prediksi faktor resiko infeksi TB paru kontak serumah untuk perencanaan program di Kabupaten OKU Provinsi Sumatera Selatan. Laporan Akhir; November 2010.

23. Fajriah R, Rusdi A, Netti S. Hubungan antara pembentukan scar vaksin BCG kejadian infeksi tuberkulosis. J Kes Andalas. 2016;5(2):381-4. 